\title{
Ketua Editor
}

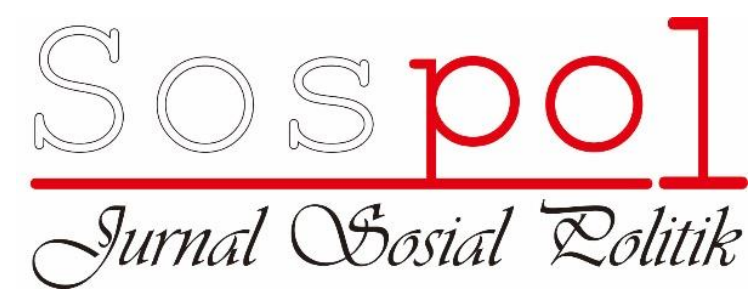

Demeiati Nur Kusumaningrum, M.A

\section{Dewan Editor}

Hafid Adim Pradana, M.A

Najamuddin Khairur Rijal, M.Hub.Int

Nurudin, M.Si

Tonny Dian Effendi, M.Phil

Winda Hardyanti, M.Si

\section{Dewan Penyunting}

Dr. Asep Nurjaman, M.Si

Himawan Bayu Patriadi, M.A., Ph.D

Myrtati Dyah Artaria, M.A., Ph.D

Dr. Tri Sulistyaningsih, M.Si

Dr. Vina Salviana Darvina Soedarwo, M.Si

\section{Penerbit}

Pusat Kajian Sosial dan Politik (PKSP)

Fakultas Ilmu Sosial dan Ilmu Politik, Gedung Kuliah Bersama (GKB) I, Lt. 6

Kampus III Universitas Muhammadiyah Malang

Jl. Raya Tlogomas No. 246, 65144 Malang, Jawa Timur. Telp. (0341) 464318-319

ext.132. Website: pksp.umm.ac.id

\section{Redaksi}

E-mail: jurnalsospol@umm.ac.id / jurnalsospol@gmail.com

Website: ejournal.umm.ac.id/index.php/sospol 